\title{
Industries English Language and Communication Need Analysis in Albania
}

\section{Elsa Zela}

\author{
PhD Psychology-Education Department, Faculty of Social Sciences, EUT, Albania
}

\section{Doi:10.5901/ajis.2015.v4n3s1p363}

\begin{abstract}
During the twentieth century, the demand for English language has been steadily increasing, "especially in countries where English is taught as a foreign language" (Hutchinson and Waters, 1987). The global expansion of trade and economy, gave rise to new developments in a world of international relations regarding various aspects of communication, the exchange of information using science and technology, business related communication as well as traveling the world for different personal or/and business reasons. This study focuses on two main issues of English for communication purposes: a) English language and communication need analysis for industries, seen it from the perspective of the employers such as human resources offices and senior managers, the need for English language and communication from the perspective of employees, and b) therefore aims to provide an overview where it can be seen whether the "demand" for English and communication necessary to perform daily functions in a company complies with " supply ", skills and competencies that the employees have obtained during the study of English at a university or other educational institutions. Through questionnaires, it is intended to identify the English language skills required from industry employees to use in working environments as well as the degree of difficulty encountered in performing the required tasks. The respondents in this study include employees and employers of industries at the level of managers and pople working in the sales, marketing, purchasing, advertising department etc.
\end{abstract}

Keywords: Communication for professional purposes, industry and business needs analysis, communication skills.

\section{Overview of the Concept of Language and Communication for Professional Purpose}

The concept of language and communication for professional purpose arises from the use of language interests and professional communication in a second language and serves the purposes of the use of language and effective communication in professional environments. Furthermore, it is intentional human interaction, which reflects the working knowledge of professionals. Effective communication in occupational settings is important in companies with diversity in the workplace. Good communication skills help reduce barriers raised because of language and cultural differences. Effective communication increases productivity, reduce errors and makes work run smoothly.

In the field of second language acquisition, the key word "language" has been clarified by many scholars. According to Common European Framework of Refences (CEFR, 2001) the current concept of understanding on the acquisition of a second language is that "the 'language' to a student includes many different aspects of "communicative competence". Littlewood further explains that "these include different competencies such as linguistic and discourse competence, the pragmatic competence, sociolinguistic competence and socio-cultural competence (Littlewood 2006: 503).

From linguistics perspective the word "communication" has been extensively used and mentioned somewhat in many contexts, such that of 'teaching communicative language " known by language teaching professionals. Fiske states that "communication is one of those human activities that everyone recognizes but few can satisfactorily outline " (Fiske 1990: 1).

What is typical about communication is that it occurs in the workplace, such as "social institutions where resources are produced and regulated, solve problems, playing with identities and form professional knowledge" (Sarangi \& Roberts 1999:1). Following this reasoning, socio-cultural "jobs are held together through communication practices" (ibid :1).

The professional setting of business and industry illustrates the utilitarian discourse system where language and communication serve purposes of global business and industry". (Scollo \& Scollo 2001),

According to Foucault and Candlin, "practice varies between areas of social discourse (telecommunications, banks, hospitals, law), where each of which evolves its own discursive practices related to a particular social field or institution". (Foucault 1982; Candlin 2005, 2006). Language activities intertwine with social activities interdependently, giving way for the formation of that field of specialization and ethnographic institution environment for communication.

One major challenge for the mastery of communication is its constant changing nature. 
In general, communication involves more than a specific verbal text; It may also include other aspects of communication such as non-verbal communication, tone of the voice, body language, space, wardrobe, attitude and behavior, which are sometimes considered less important in the area of English for specific purposes. In order to communicate fluently, interlocutors must possess the communication skills, which are defined in English language teaching as listening, reading, speaking, writing and mediation (CEFR 2001);. It uncommon that they might occur separately in a professional setting, but rather as integrated groups of subskills.

Professional communication in the workplace is used for various purposes. The scholars Poole and Hirokawa identify six of these purposes: (1) social information processing that is, a combination of existing information, generating new information, the development and the combination of information elements, (2) professionals communicate analytic functions such as the analysis of unforeseen circumstances around situations where choices must be made. (3) A large part of the communication in the workplace has to do with maintaining the systems, establishing rules for making a decision. These are called procedural functions. (4) Communication can also be obtained with functions related to an order, that is the determination of the values and goals we set or monitor them. (5) The synergistic functions involves the coordination and motivation of the management that occur in situations and (6) rhetorical functions such as persuasion, social influence and leadership are used for example in the discourse of a job interview or negotiation (Hirokawa \& Poole 2004: 12).

According to Candlin the discourse of professional communication is centralized towards the knowledge of discursive practices and necessary forms of discourse. Scollo in (Scollo \& Scollo 1995) declare that discursive practices can sometimes be specific to a profession such two mechanical engineers communicating with each other, but often communication includes meetings with a number of professionals in cases of interdiscursive practice.

Summing up, the system of communication for professional purposes is dynamic and goes through constant change. As a result, these characteristics can be enhanced in the definition of needs analysis for language and practice of analysis necessary for language.

\section{Objectives of the Study}

This paper aims to shed light on the English language communication skills required by employees and employers in the industry sector. Specifically, the study tries to reveal some of the ways and functions of the use of English for communication that employees in different departments in four multinational companies in Albania regard as necessary to perform their functions in the premises where daily work is performed. Through questionnaire surveys and interviews completed by more than 75 employees, the study tries to determine which is the proportion of daily tasks which require communication in English and what are English language skills that are used most often. Also, an attempt was made to determine the degree of difficulty that these workers encounter in the use of English to perform these tasks. This study will only discuss the findings up to this point of the study. On the broader scale, this study which is part of my doctoral thesis, will use the data collected to be further compared with the program of English language for specific purposes in the Faculty of Economics and Agribusiness, Agricultural University of Albania. The comparison will be done in terms of reviewing whether whati is taught at university complioes with the workplace requirements for language and communication in English. The analysis of the compliance or non-compliance of English language skills, will be helpul to the program-designers as well as employers in order to respond effectively to the language needs of employees/ers in industries in Albania

\section{Research Question, Hypothesis and Methodology}

A quantitative approach is used in this study, which through quantitative techniques investigates the English language and communication needs of people employed in different department in four main industry and bussiness companies. The main method used in the study is the questionnaire. The questionnaire consists of a scale of Likert type. The data were analyzed by SPSS and the findings received were interpreted objectively. The basis of the questionnaire has been taken form a the questionnaire used by Bhatia and Candlin and modified according to the needs of the study and context (Bhatia \& Candlin, 1998). A sample of 75 of employees employed in different departments at management level and other departments in companies which have employed students graduated in the field of economy filled in the questionnaire. Initially, contact was established with 4 large industry companies operating in Albania, two of them in the field of production of cement and 2 others in oil extracting and processing. Through e-mails their participation in the study was requested. Questionnaires benefited from the sample of 75 of employees bring details and different communication 
aspects of their work and the language used and needed. Before questionnaire administering, employees were assured that this study takes place simply for research purposes, the data are confidential by preserving anonymity.

\section{4. $\quad$ Research Questions}

This study tries to answer the following three questions:

1. What are the English language skills, employees in industry use more often in their work environment?

2. What actions / tasks are included in communication in English?

3. What are the difficulties encountered in carrying out the actions required?

\section{Analysis, Data Interpretation}

This section presents an overview of the 170 participants along with the information they brought by filling in questionnaires. Part of "General Information" of the questionnaire was grouped into two main sections. The first part concentrates around personal data of the participants that are related to gender, age, education, duration of work in the comany, and job position they hold. The second part describes information related to their perceived importance of the English language in respective job position and relative level of English language skills.

\subsection{General information}

The first part of the questionnaire has been devoted to collecting general information on participants such as gender, age, education, length of work in the current company and job title. Most participants in the survey result females (58\%), versus $42 \%$ of men. Regarding the age of the employees the highest percentage of participants $45 \%$ belong to $31-40$ years old category and participants aged 51-60 years old were small in number (9\%). Regarding education, the majority of participants (51.4\%) have a bachelor degree, $45 \%$ hold a master degree, no employee resulted with lower than bachelor degree, and 3 of them have PhD degree. Most participants in the survey (52\%) have been working in the current company for more than 5 years, while only $4 \%$ have been working for less than a year.

$\begin{array}{ll}\text { Job position } & \\ \text { Finance department } & 12 \\ \text { Sales department } & 8 \\ \text { Purchase department } & 12 \\ \text { Marketing } & 8 \\ \text { Human resources department } & 12 \\ \text { Quality management } & 12 \\ \text { Foreman } & 11\end{array}$

5.2 Perceived information on the importance of English language and communication in the participants job and the their respective skill level.

Most participants in the interview (35\%) think that English is important in their work. Furthermore, 27\%, 10\%, 20\% respectively stated that English was moderately important, little important, and very important. A percentage of roughly $8 \%$ regard English as the least important in their work.

In terms of skills, a good part of the staff (42\%) felt that their level of English is good and 17\% thought that their level of English was elementary. 22\% of respondents stated that their level of knowledge in English was advanced. The rest, about $19 \%$ denied to respond.

\subsection{The perceived necessity for English language}

This section describes the views of participants around their necessity for English language identified in skills. Evaluations were made at 4-point Likert scale. English was considered as necessary by all respondents. All skills are conidered as needed especially speaking with a 3.67 average, followed by interacting with an average of 3.13 , listening with an average of 3.11, writing with an average of 3:09. Reading has the lowest average 3:04, but it was also considered necessary. 


\subsection{The views of participants about the difficulties of English according to skills}

From the ranking of difficulties of the English language (very difficult, difficult, little difficult, not at all difficult) the majority of respondents considered English language skills as a little difficult. Only reading was perceived as not at all difficult while writing and interacting are identified to be difficult skills.

\subsection{The participants need for English listening skills}

The results suggest the need of participants for listening skills is average, attenting training was deemed necessary with the highest average (3.71), followed by listening to presentations, lectures or talks with $2: 33$, listening to instructions 2.23 , and listening to explanations and descriptions with 3:14.

\subsection{The needs of participants for English speaking skills}

Employees of companies consider as average necessary the speaking skills in English. However, the need to make descriptions and give explanations $(=4,1)$ seems to be regarded of high necessity by respondents followed by making a formal presentation 2.31 (average), making an informal presentation 2.11 (average) giving instructions or demonstration of a task-1.2 (average)

\subsection{The need of participants for English reading skills}

From the data can be observed that the activities listed under the reading section of skills grouped in tasks of reading for details in e-mails, letters, faxes, memos and short reports equals $(=3.21)$; reading quickly to grasp the general information in textbooks and professional journals equals $(=3.11)$; as well as analysis of specific details in lengthy reports, documents and contracts, technical specifications and manuals $(=3.10)$ were averagely needed.

\subsection{The needs of participants for English writting skills}

The needs for writing skills of the staff were considered as average. Writing e-mail has been rated with the highest average $(=3.45)$. On the other hand the need to write letters and faxes as well as to write reports and long articles brought roughly different values but still go around average levels 2.91 and 2.77 respectively. Finally, the need to edit letters and/or reports written by other people is rated as a little needed skill(=2.19)

\subsection{The needs of participants for Interaction in English}

Considering that functions interact, five functions including making telephone calls $(=3.71)$, visiting companies $(=2.78)$, taking part in discussions and informal meetings $(=255)$ receiving visitors $(=2.69)$, were considered moderately necessary. Interviewing on the other hand equaled $(=1.41)$, chairing meetings $(=1.69)$ and negotiating $(=1.69)$, were estimated as need less.

\subsection{Problems in the use of English listening skills}

This part of the results of the questionnaire answers the second research question: What problems are faced by employees of companies on the use of the English language? This section groups the skill again around five main areas: listening, speaking, reading, writing and interacting.

\subsection{Listening}

In general, problems with listening in English are considered average. The average of four skills that are listening to presentations, lectures or conversations $(=3.34)$, follow instructions $(=2.44)$, listening to descriptions and explanations $(=$ $3.21)$, as well as to attend training $(=3.61)$ are almost on the same scale evaluation. 


\subsection{Speaking}

Problems faced by employees when using the speaking skill in English are as follows. Participants considered the difficulty of using the speaking English language skill as average. Formal presentation was seen as more problematic with the highest evaluation $(=4.10)$, while making informal presentations was rated (3:35), task demonstration or giving instructions equaled (3:26), and describing and explaining were assessed as average.

\subsection{Reading}

Employees proved to have many problems related to reading the details in letters, short reports, e-mails, memos and faxes as well as in the ability of reading for analysis in contracts and legal documents, long reports and technical specifications being regarded as too problematic $(=4.37)$ and $(4.21)$. Quick reading general information of textbooks and professional journals was moderately difficult.

\subsection{Writing}

In relation to problems in the use of writing skill in English language, business employees and industrial companies have set the average difficulty for all categories under the writing skill. Thus, writing e-mails is rated as 23.03 , writing faxes and letters with 3:42, the respondents considered the skill of writing long articles and reports equal to $3: 26$, and editing of letters or reports of others with 3:49.

\subsection{Interaction}

In general, the questionnaire revealed that employees had average difficulty in using the skills of interaction in English. Only receiving visitors $(=3.81)$ and making calls $(=3.92)$ are considered to be difficult and the rest of skills such as visiting a company (2.81), participation in negotiation/small talk and informal meetings rated (3:15) participation in formal meetings (2.74), chairing meetings, rated (3:29), interviewing skill, rated (3 41) and negotiating skill, rated(2.67) identified by participants as skills with average difficulty.

\section{Conclusions / Recommendations}

Through the answers provided by the respondents in the questionnaire and their statistical analysis, data which can be used to answer the following research questions were collected:

1. To what extent is the need for the use of English by employees of business and industrial companies?

2. What are the problems in the use of English that employees at work face?

From questionnaires examination, it was concluded that participants perception is that English language is needed and part and parcel of their job. They also stated that it was increasingly becoming an important topic in their working envirnment since industry companies aim to provide services and the best products and quality to its customers at home and abroad in order to be complete sucessfully in the rapidly evolving business environment. Most of their skills in English fall at the lower intermediate level and therefore they think they need to boost their English skills in order to meet the objectives of companies in industry and business. The results of the study proved the speaking skill to be crucial, followed by listening. The skills of interaction and writing were equally estimated as necessary skills while reading was considered as less necessary.

As the findings of this study provide a clear picture of the needs and problems of employees in business and industry, they can be useful for training for those responsible for planning policies. The results can provide guidelines to design, develop and revise and effective courses in teaching Business English and teaching resources for staff. Needbased curriculum and teaching materials and resources specifically designed would encourage progress in skills through various training in the workplace and would enable those employees to use language effectively at work.

\section{References}

Bhatia, V. K., \& Candlin, C. N. (1998). The law society of Hong Kong project: strategies and competencie in legal communication - a study to investigate the communicative needs of legal professionals. Hong Kong: City University of Hong Kong.

Carnevale, A. P., Gainer, L. J., \& Meltzer, A. S. (1990). Workplace basics: the essential skills employers want. San Francisco: Jossey- 
Bass Publishers.

Chew, K.-S. (1999). Multiple discourses in business education: occupational perspective - the interface between the academy and the business world. Paper presented at the 12th World Congress of Applied Linguistics (AlLA 99, August, Tokyo).

Chew, K.-S. (2000). Money talks: an investigation into the professional discourse of employees in the Corporate Communications Department of a medium-sized bank in Hong Kong. Unpublished rawdata of Thesis, University of York, England.

Common European Framework of References (CEFR 2001);

Evans, S. (1999). Workplace communication in a time of transition: the case of Hong Kong s construction industry. Hong Kong Journal of Applied Linguistics, 4(2), 57-78.

Firth, Alan and Johannes Wagner (1997). On discourse, communication, and (some) funda-mental concepts in SLA research. Modern Language Journal 81: 285-300

Fiske, J. (1990) Introduction to Communication Studies. London/NewYork: Routledge.

Foucault, M (1982) Power/Knowledge: Selected Interviews and Other Writings by Michael Foucault,1972-1977. New York: Pantheon

Green, C., \& Evans, S. (2000). A survey of language use in the professional workplace in Hong Kong.

Hirokawa, R.Y., Erbert, L. \& Hurst, A. (2004) Communication and Group Decision-Making Effectiveless.In R.Y. Hirokawa. \& M. S. Poole (eds) Communication and Group Decision Making. 2nd edition. Thousand Oaks: Sage.

Hutchinson,T. and Waters, A. (1987). English for Specific Purposes: A learning-centred approach. Cambridge: Cambridge University Press

Littlewood, W. 2006 (2004) Second Language Learning. In A. Davies, \& C. Elder (eds) The Handbook of Applied Linguistics, $501-24$. Malden, MA, USA etc: Blackwell Publishing.

McCrum ,R (2010) GLOBISH: How the English Language Became the World's Language

Munby, John. 1978. Communicative syllabus design. Cambridge: Cambridge University Press

Richterich R. and Chancerel J-L. 1980. Identifying the Needs of Adults Learning a Foreign Language. Oxford: Pergamon Press.

Robinson, P. 1991. ESP Today: A Practitioner's Guide. London: Prentice Hall

Sarangi, S. and Roberts, C.(eds) (1999) Talk, work and institutional order. Discourse in medical and management settings. Berlin: Mouton de Gruyter.

Scollon, R.\& Scollon, S.W. 2001(1995) Intercultural Communication - A Discourse Approach.Blackwell Publishing.

Stevens, P. 1980. Teaching English as an International Language: From practice to principle. Oxford: Pergamon Press

Trochim, W. M. 2006. Research Methods Knowledge Base (Online). http://www.socialresearchmethods.net/kb/, April 28, 2007.

Widdowson, H.G. 1983. Learning Purpose and Language Use. Oxford: Oxford University Press. 